\title{
Implications of Oil Inflows for Savings and Reserve Management in the CEMAC
}

\author{
Paulo Drummond
}





\title{
IMF Working Paper
}

\author{
African Department \\ Implications of Oil Inflows for Savings and Reserve Management in the CEMAC \\ Prepared by Paulo Drummond
}

Authorized for distribution by John Wakeman-Linn

October 2007

\begin{abstract}
This Working Paper should not be reported as representing the views of the IMF. The views expressed in this Working Paper are those of the author(s) and do not necessarily represent those of the IMF or IMF policy. Working Papers describe research in progress by the author(s) and are published to elicit comments and to further debate.

This paper argues that as part of their fiscal optimization strategies CEMAC countries should be given the opportunity to invest into longer-term assets that generate market-based returns. The BEAC has created a framework of longer-term savings funds but due to low remuneration and other factors usage has remained limited. The paper also argues that regional savings in the form of reserve accumulation must be sufficient to ensure the stability of the common currency. While the current level of common foreign reserves may now be appropriate, maintaining an adequate level calls for a link between country-specific savings decisions and the setting of a regional reserve target. Strengthening and diversifying reserve management will also be desirable, a process the BEAC has embarked upon.
\end{abstract}

JEL Classification Numbers:E61, E65, F31

Keywords: Oil Inflows, Foreign Reserves, Reserve Management

Author's E-Mail Address:PDrummond@imf.org 


\section{Contents}

I. Implications of Oil Inflows for Savings and Reserve Management in the CEMAC .............3

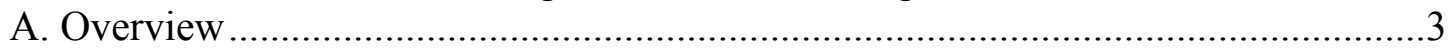

B. The Anatomy of the Oil Inflows ...................................................................

C. Policy Implications: Oil Savings and Reserve Management Frameworks ...............7

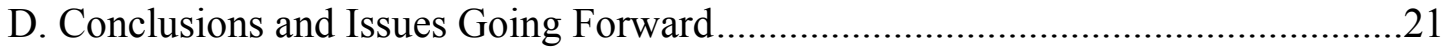

Tables

1. Comparisons of International Reserves across Regions, 1995-2006 ..............................14

2. CEMAC: Implied Reserve Need ............................................................................. 17

3. Optimal Level of Reserves_-Calibration of Parameters ..................................................18

Figures

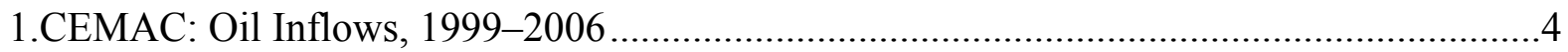

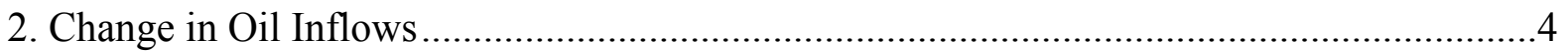

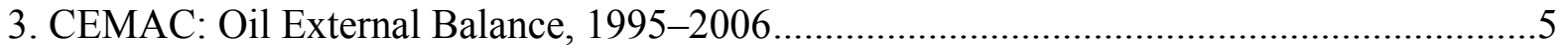

4. CEMAC: Oil Fiscal Revenues ..................................................................................6

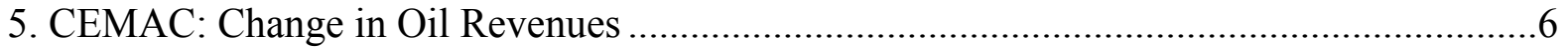

6. CEMAC: Change in Non-Oil Fiscal .......................................................................... 7

7. CEMAC: Change in Non-Oil Current Account............................................................... 7

8. CEMAC: Currency Cover Ratio, 1994-2006 ..................................................................9

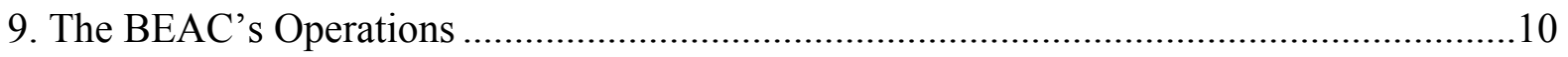

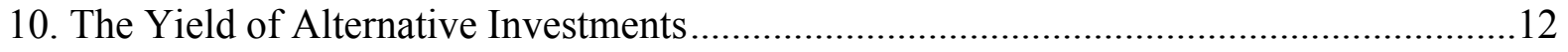

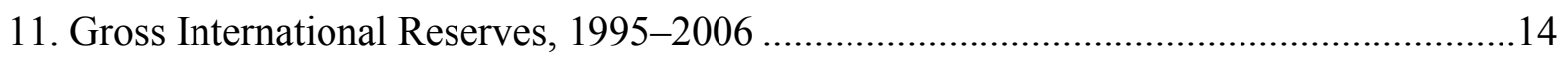

12a. Thresholds for International Reserves, 1995-2005 ................................................15

12b. Thresholds for International Reserves 1995-2005 .....................................................16

13. Reserve Coverage Under Different FFG Assumption ................................................... 19

14. International Reserves Under Different FFG Scenarios ................................................20

Boxes

1. Remuneration of Government Deposits by BEAC ...................................................... 10

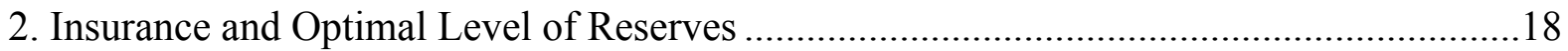

3. The Concept of Strategic Asset Allocation.................................................................21

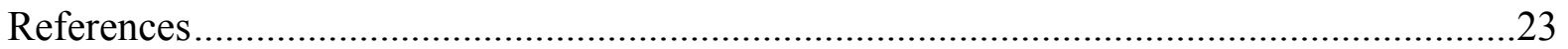




\section{IMPlications OF OIL INFLOWS FOR SAVINGS AND RESERVE MANAGEMENT IN THE CEMAC}

\section{A. Overview}

1. The large oil-related inflows experienced by most countries of the Central African Economic and Monetary Community (CEMAC) pose new macroeconomic challenges. Most CEMAC countries substantially increased their oil exports and their fiscal revenues in recent years. The policy challenges for CEMAC governments are to decide how much to scale up public spending on goods, services and investment projects; how much to absorb through higher net imports; and how to allocate savings from the boom.

2. While each country must address these challenges for itself, participation in the monetary union affects the choices. One factor is the need to coordinate national fiscal policies to keep the currency stable in terms of the euro. A second is the requirement to repatriate and pool foreign assets at the Central Bank (BEAC), which constrains savings choices. These requirements are articulated in the regional framework for fiscal policy coordination and reserve management.

3. Large oil inflows have reduced the relevance of the existing regional framework for coordination of fiscal policy and accumulation of foreign exchange. The oil surpluses have rendered the fiscal convergence criteria not binding, and the framework does not provide guidance for coordination of member fiscal responses to the boom; nor does it contain an effective mechanism for long-term fiscal savings that would also allow for preserving adequate monetary reserves. These issues are not yet fully resolved, although the BEAC did reform the framework for government deposits and introduced a grid of deposit remuneration in 2006.

4. This paper argues that management of the oil booms would benefit from improvements in the existing regional coordination framework. While savings decisions reflect individual country circumstances, regional guidance would support better coordinated and more sustainable fiscal policies. Similarly, while pooling reserves has proved useful and should be preserved, creation of savings funds with remuneration linked to market returns should also be possible. This would require changes in the reserve management framework that would nevertheless aim to maintain reserve adequacy. Such changes are more pressing in light of the need to manage the oil booms well.

5. The paper is organized as follows: Section B discusses the nature of the oil inflows by country and reviews country policy responses to date. Section $\mathrm{C}$ discusses regional policy implications with a focus on the management of oil-related savings and foreign reserves. Section D concludes. 


\section{B. The Anatomy of the Oil Inflows}

6. Total external oil inflows to the region-25 billion US\$ dollars in 2006-were higher by some 10 percent of regional GDP in 2003-2006 than inflows in 1999-2002 (Figures 1 and 2). The additional oil receipts reflect higher world oil prices and significantly increased production output in some countries. Except for the Central African Republic (CAR, not an oil producer) and Cameroon (where the decline in oil production more than offset the rise in prices), the other CEMAC countries (Chad, Congo, Equatorial Guinea, and Gabon) substantially increased their oil exports.
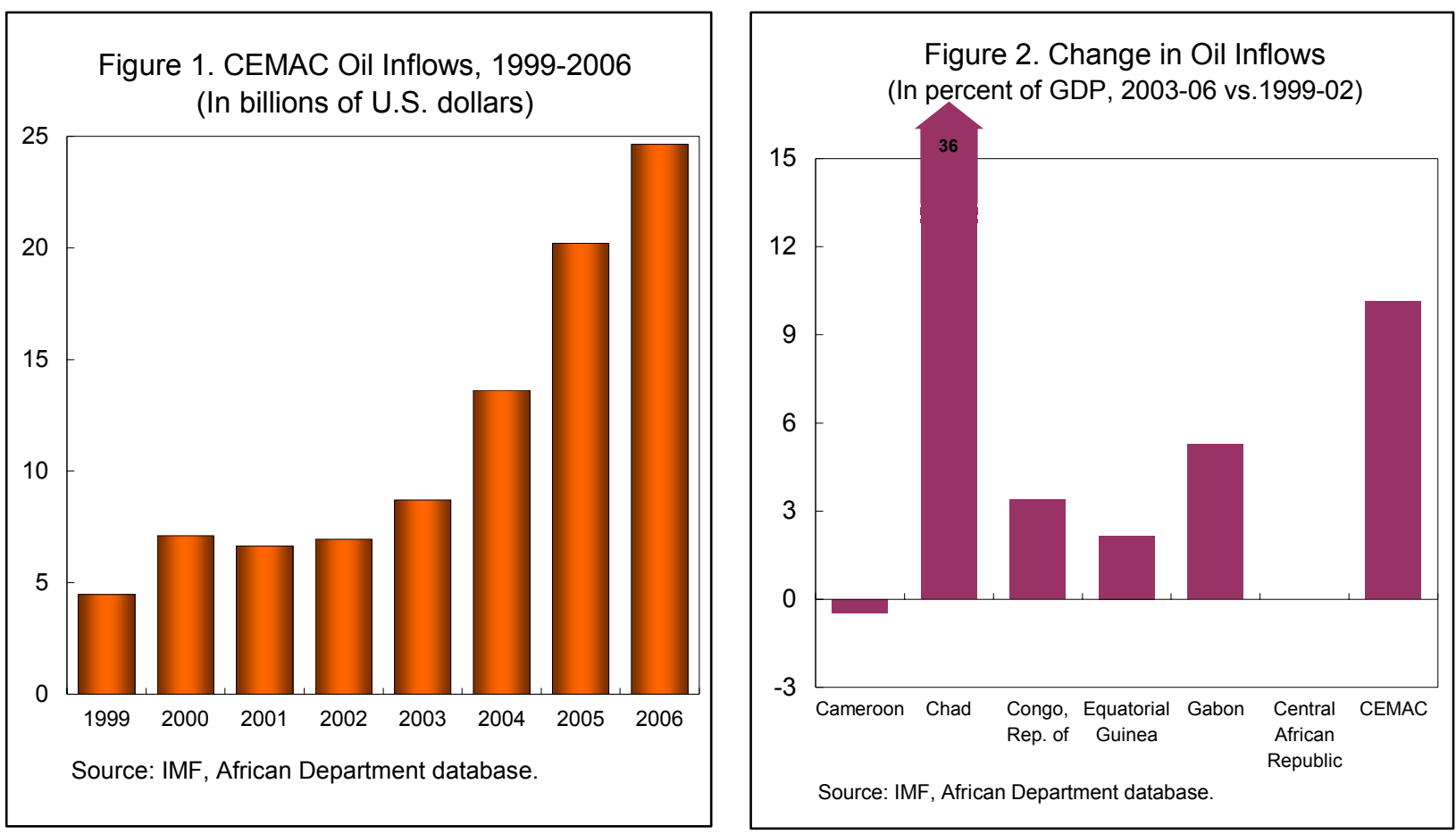

7. The timing, intensity and duration of the booms varied (Figure 3). Chad moved from large negative oil balances before 2003 - with costs for initiating oil extraction - into surpluses thereafter. In Congo, Gabon and Equatorial Guinea, the surge in inflows did not imply a swing in the external oil balance (net oil exports), but rather gradual increases from previously steady levels. While the rise in oil prices is responsible for a substantial part of the increase in all the CEMAC oil producers, production also expanded significantly in Chad and Equatorial Guinea.

\section{For the CEMAC as a whole, government oil revenues also increased} substantially (Figures 4 and 5). Revenues from oil surged to 20 percent of GDP for the CEMAC by the end of 2006, some 10 percentage points more than the average for 19992002. Again, country experiences varied; oil revenue accounted for more than half of all revenues in Congo, Equatorial Guinea, and Gabon. 
Figure 3. CEMAC: Oil External Balance, 1995-2006 (In percent of GDP)
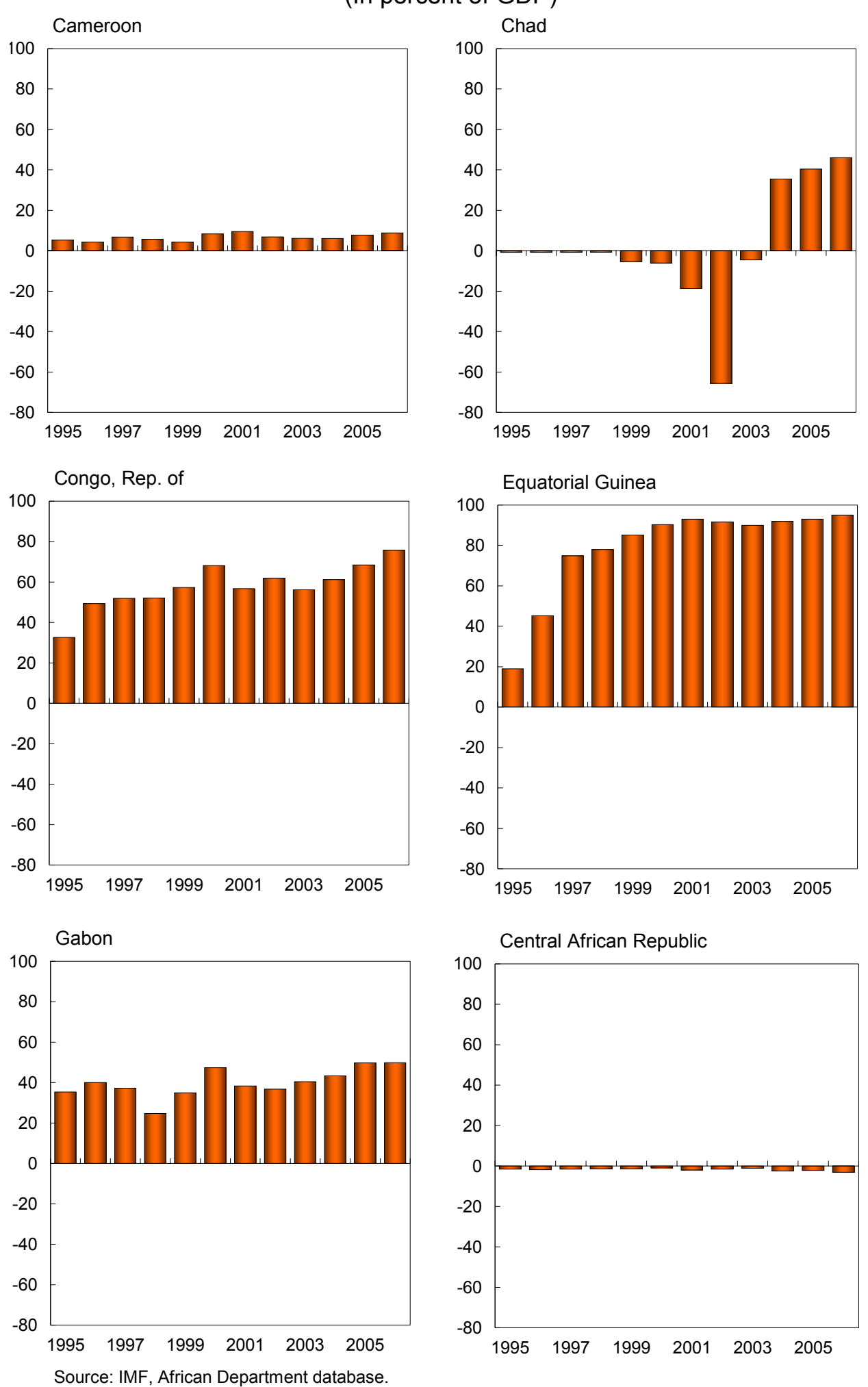

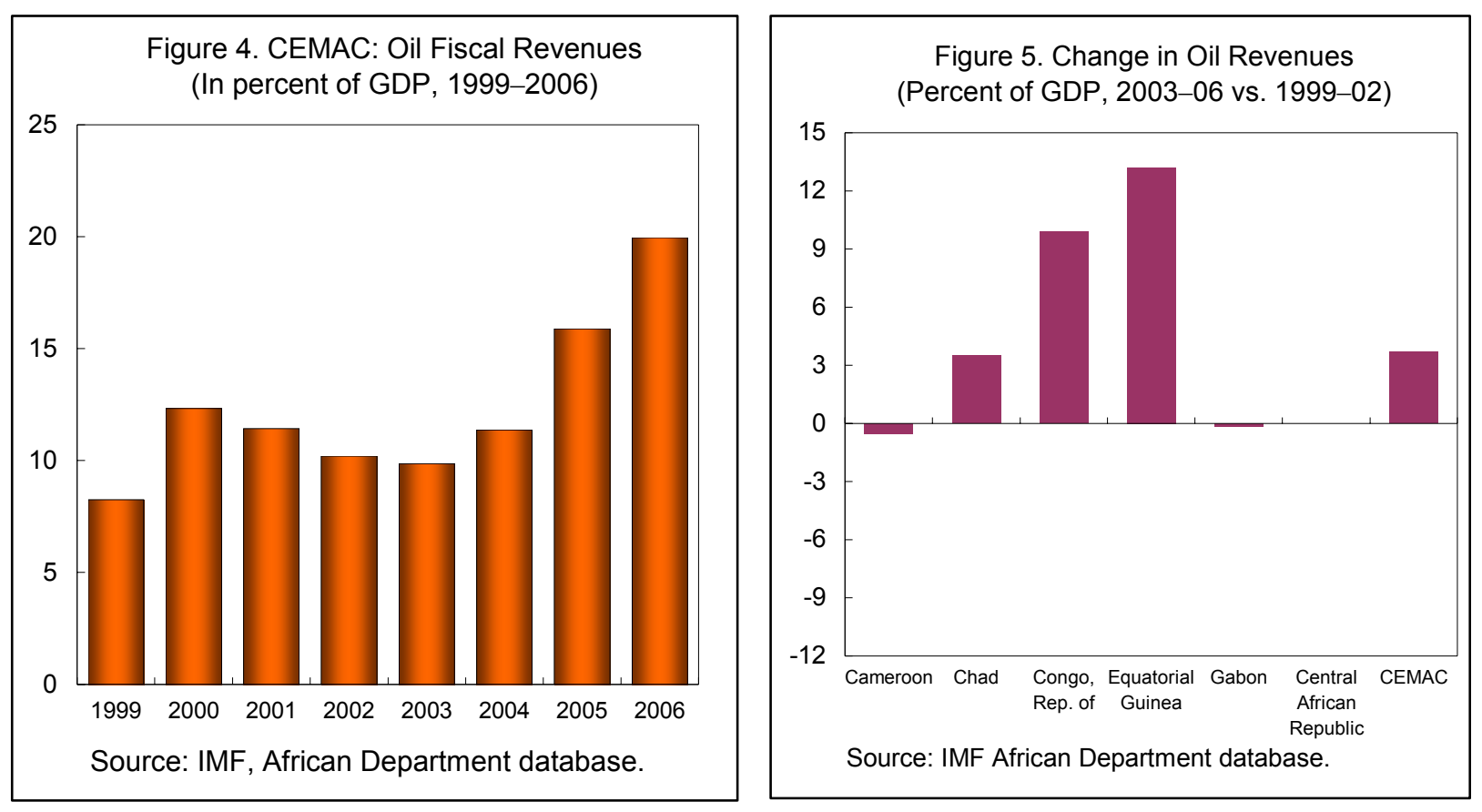

\section{How have oil-exporting CEMAC countries handled the higher oil revenues?}

Whereas the ratio of government oil revenue to non-oil GDP jumped on average from 14 percent in 1999-2002 to 23 percent in 2003-2006, non-oil fiscal deficits were stable at about 14 percent of GDP, reflecting higher non-oil fiscal revenues (Figure 6). On average, some 40 percent of oil exports accrued to governments as fiscal revenue in 2003-2006. In countries that had more public-private production-sharing arrangements, a lower share of oil export receipts accrued to the government. In new oil exporting countries like Chad, the share was about 10 percent, compared to 60 percent in Cameroon, a more mature oil producer.

\section{How much of the higher export receipts have CEMAC countries absorbed?}

In Chad, Equatorial Guinea and Gabon, non-oil current account balances did deteriorate after the growth in oil inflows (Figure 7). Whereas the ratio of oil inflows to non-oil GDP jumped on average from 40 percent in 1999-2002 to 61 percent in 2003-2006, non-oil current account deficits deteriorated from 46 percent of non-oil GDP to 62 percent. In Congo, however, the non-oil current account balance improved. 

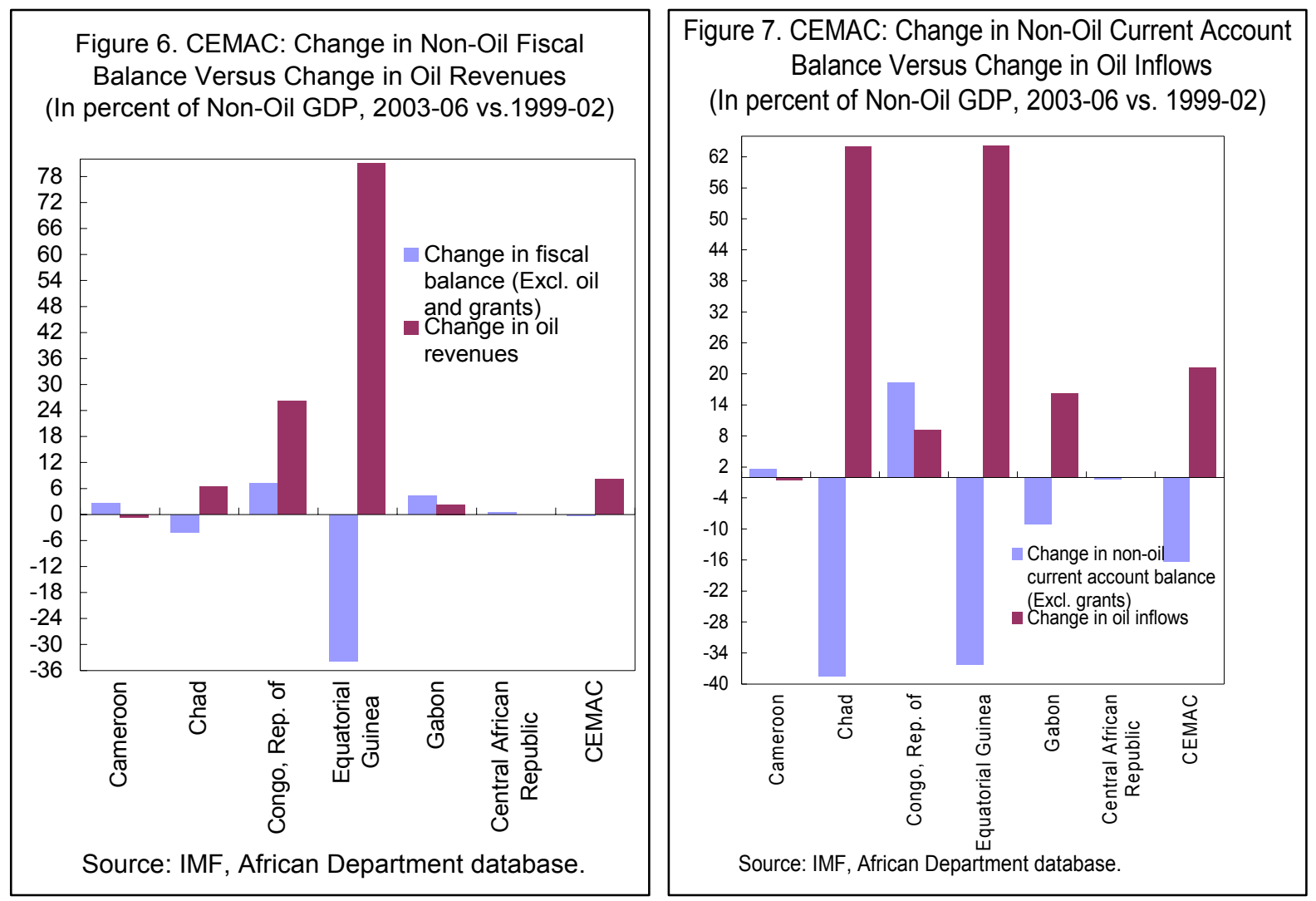

11. In sum, the policy responses to the oil booms have varied across the CEMAC countries reflecting country preferences with respect to balancing spending needs against absorption capacity and the desire to save part of the oil inflows for future generations. Chad and Equatorial Guinea, new oil producers, expanded expenditures and widened their non-oil fiscal deficits between 1999-2002 and 2003-06. At the same time, Chad absorbed about two-thirds of the inflows, while Equatorial Guinea absorbed about half of the inflows. In Congo and Gabon, more mature oil producers, the impact of higher oil revenues reflected their initial fiscal positions, and while Gabon allowed for partial absorption of over half of the inflows, Congo did not. Looking forward, additional oil inflows will require careful management and investment of oil related savings, the subject of the following section.

\section{Policy Implications: Oil Savings and Reserve Management Frameworks}

\section{The accumulation of foreign assets beyond the level considered sufficient for} balance of payments needs would allow countries to save oil income. For each country the optimal saving profile depends on the initial oil endowment, the stage in the oil production cycle, development needs and absorption capacities, but a prime consideration at the regional 
level is the need to keep reserves adequate. This section reviews how reserves are currently managed and draws implications for managing oil saving and reserves. ${ }^{1}$

\section{The current setting}

13. The management of reserves in the CEMAC is guided by the existing monetary cooperation agreements with France. These agreements are based on a fixed parity against the euro, with full convertibility of the CFA francs issued by the BEAC guaranteed by the French Treasury; and, on the pooling of reserves. All export earnings must be repatriated and a minimum of 65 percent of foreign exchange earnings must be deposited in the operations account with the French Treasury; the remainder can be invested elsewhere according to BEAC's own reserve investment rules. ${ }^{2}$ The entry of France into the euro zone did not affect these agreements.

\section{The current arrangement is structured to prevent or limit drawings on the} overdraft facility (the BEAC operations account at the French Treasury). This includes a floor on the BEAC's foreign assets in the operations account with the French Treasury; the requirement of a minimum level of net foreign assets equivalent to at least 20 percent of sight liabilities; and the provision that limits credit to the governments by the BEAC of the members countries to 20 percent of tax revenues in the previous year. These limits are complemented by procedures for addressing shortfalls in reserves. BEAC regulations stipulate that whenever a member country has a debit position on the operations account, it must take remedial action. A decline in reserve coverage to less than 20 percent of sight liabilities for three consecutive months triggers emergency measures. If the operations account as a whole is overdrawn for 30 days, the scope for refinancing is reduced.

\section{Current reserve pooling arrangements call for all oil-related foreign currency} inflows to be deposited with the BEAC. This has contributed to the BEAC's build-up of comfortable amounts of reserves over the past several years and has helped increase transparency of oil-related income. Recent increases in oil inflows have helped bolster BEAC reserves to about 9 billion U.S. dollars, more than 100 percent of base money, and far above the 20 percent coverage requirement set out in BEAC statutes (Figure 8). Coverage varies by country, though; Equatorial Guinea has above average reserves.

\footnotetext{
${ }^{1}$ For a broader discussion of financial sector issues, see IMF (2006), Central African Economic and Monetary Community - Financial Sector Stability Assessment, SM/06/201.

${ }^{2}$ The BEAC has agreed with the French Treasury to gradually lower the share of foreign exchange reserves (excluding the counterpart of the Funds for Future Generations) to be held with the French Treasury from 65 percent to 60 percent in July $1^{\text {st }} 2007,55$ percent in July $1^{\text {st }} 2008$ and 50 percent on July $1^{\text {st }} 2009$. As of end2006, the BEAC managed less than 10 percent of its reserves itself, with a rate of return on its French Treasury Account of 100 basis points more than the ECB policy rate.
} 


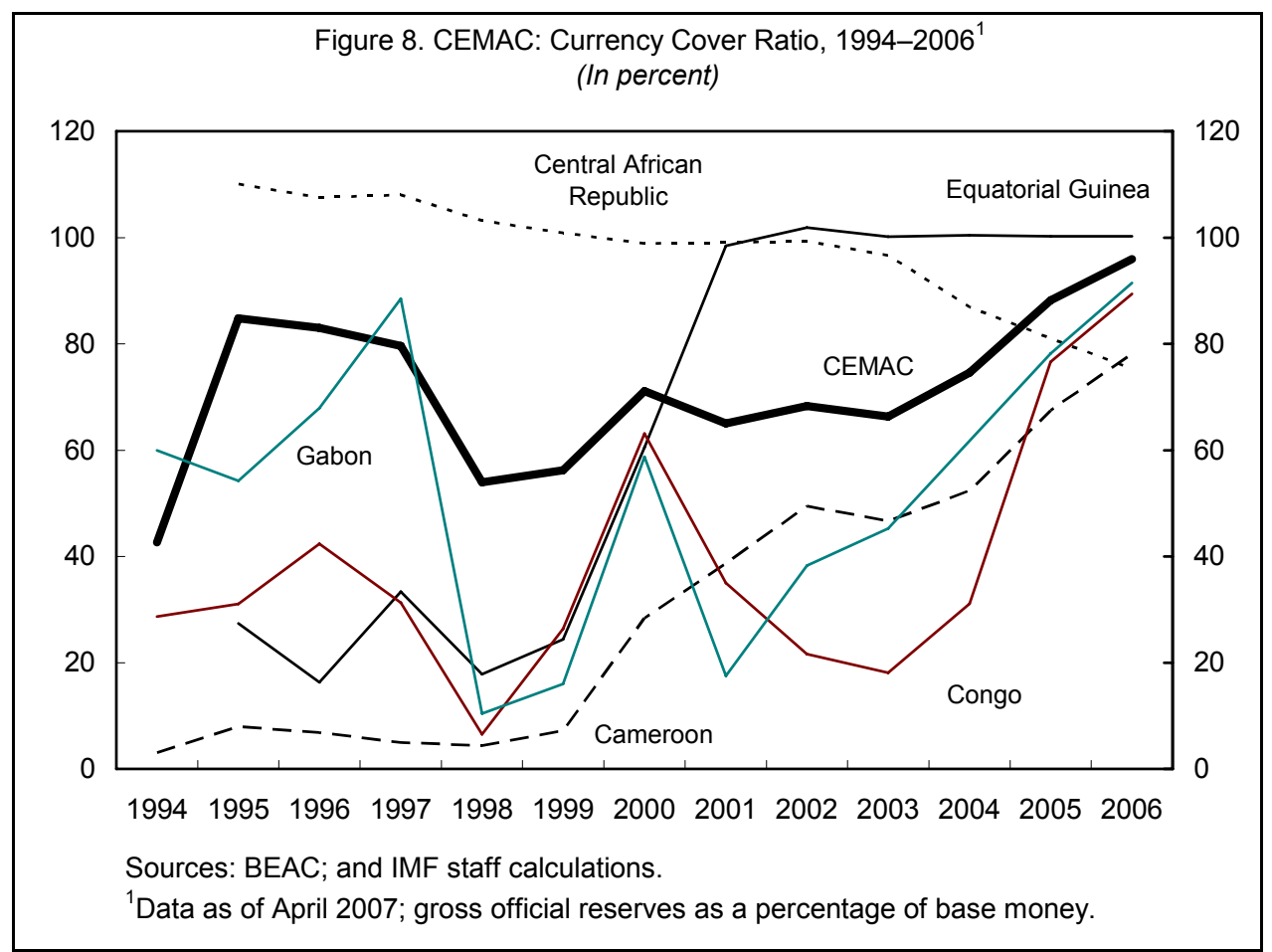

16. Since 2006 the BEAC has offered local currency denominated savings funds(Funds for Future Generations (FFGs) and Oil Stabilization Funds (OSFs)) - but to date usage remains low. FFGs and OSFs are CFA-denominated accounts in the BEAC. Countries may set aside in the funds any amount that is consistent with domestic fiscal targets. The interest rate has been linked to BEAC earnings on its French Treasury operations account (ECB policy rate plus 100 basis points-4.75 percent as of April 2007) (Box 1 and Figure 9). Total return to countries also depends on BEAC realized profits. ${ }^{3}$ After July 1 , 2007, long-term deposits will no longer be included in the pool from which the share of reserves going to the operations account is calculated. ${ }^{4}$

\footnotetext{
${ }^{3}$ BEAC profits net of operating costs are distributed to member states after provisions as follows: 15 percent to all members in an equal amount; 15 percent according to each member's share in currency in circulation; and 70 percent according to each member's relative contribution to the central bank's profits.

${ }^{4}$ The Convention de Compte d'Operations excludes the counterpart in foreign assets of government deposits of over one year with BEAC.
} 


\section{Box 1. Remuneration of Government Deposits at BEAC}

Government deposits earn interest based on the interest the BEAC earns on its deposits with the French Treasury minus a margin to ensure BEAC profitability.

Conventional deposits (dépôts spéciaux classiques). One-month minimum maturity. Remuneration for countries with outstanding advances from BEAC is 0.5 percent, and for other countries 2.8 percent.

Fiscal Revenue Stabilization Mechanisms. Six-month minimum maturity. Interest rate as of June 2007 was 3.1 percent, subject to a 30 percent reduction for withdrawals before maturity.

Fund for Future Generations. Minimum maturity of five years. Interest rate as of June 2007 was 3.3 percent subject to a retroactive reduction for withdrawals before maturity.

Interest on Government Deposits at the BEAC

\begin{tabular}{lrrrrrr}
\hline & Apr. 06 & Jun. 06 & Aug. 06 & Oct. 06 & Dec. 06 & Mar. 07 \\
\hline Regular Government Deposits & 1.4 & 1.7 & 2.4 & 2.6 & 2.7 & 2.8 \\
Oil Stabilization Funds & 1.7 & 2.0 & 2.7 & 2.9 & 3.0 & 3.1 \\
Funds for Future Generations & 1.9 & 2.2 & 2.9 & 3.1 & 3.2 & 3.3 \\
$\begin{array}{l}\text { Memorandum item: } \\
\begin{array}{l}\text { Interest on the Operations } \\
\text { Account }\end{array}\end{array}$ & 3.5 & 3.8 & 4.0 & 4.3 & 4.5 & 4.8 \\
\hline
\end{tabular}

Source: BEAC.

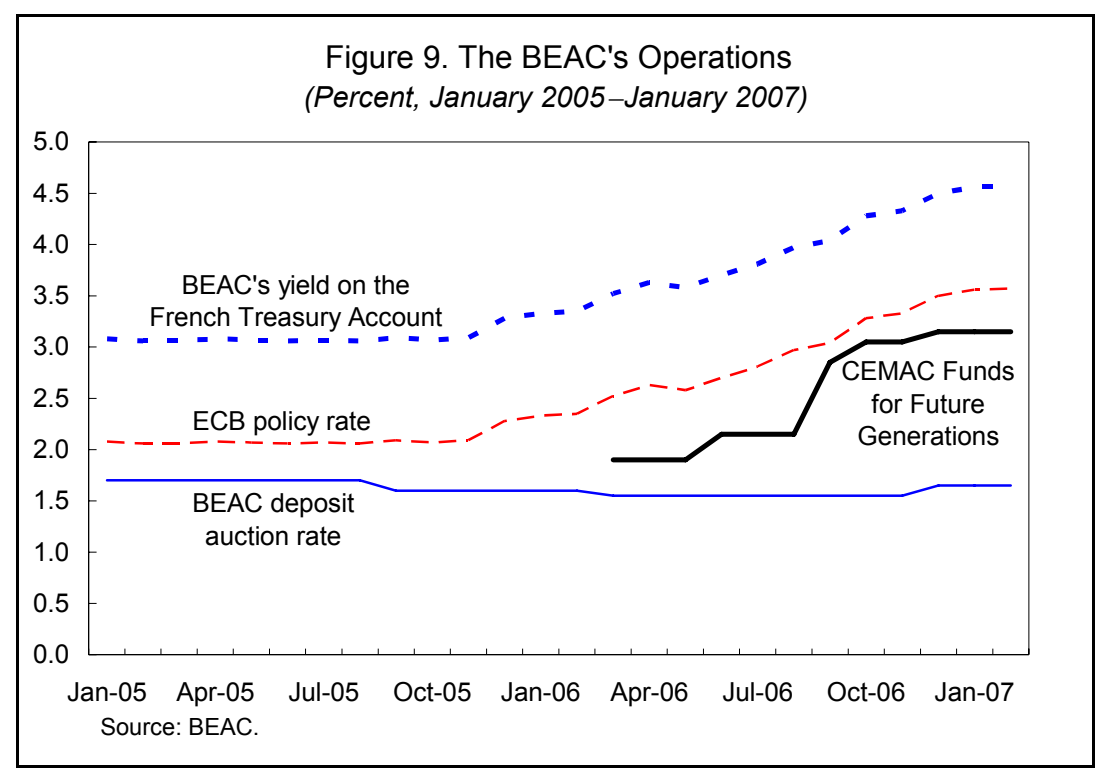

\section{Economic policies are coordinated through a multilateral surveillance}

arrangement. The goal is to keep national fiscal policies consistent with the common monetary policy. The CEMAC Executive Secretary implements surveillance in consultation with the BEAC based on criteria for defining an excessive fiscal deficit and on macroeconomic indicators for monitoring and interpreting economic developments in the 
member states. ${ }^{5}$ A fiscal deficit is deemed to be excessive if it is incompatible with monetary policy objectives, particularly with regard to financing the deficit and foreign exchange cover for currency issuance. The four convergence criteria that have been defined are: (i) a nonnegative basic fiscal balance; (ii) average annual inflation rate of no more than 3 percent; (iii) a level of public debt that is no more than 70 percent of GDP; and (iv) no increase in internal or external arrears in the current year.

\section{Forward looking challenges}

18. While the existing reserve policy and management framework has many positive features, a number of challenges remain:

- Determining the level of government savings needed for coordinating monetary and fiscal policy. BEAC's regional monetary program takes into account each country's public finances and economic forecasts, with a view to calibrating the volume of bank refinancing. But while fiscal policy in CEMAC countries is conditioned by a fiscal convergence criterion requiring a zero-basic balance, in the context of fiscal surpluses, this criterion has lost much of its significance. So has the limit on Central Bank credit to the government ("avances statutaires") of 20 percent of fiscal revenue in the previous year.

- Distinguishing between monetary reserves and fiscal savings. BEAC manages the FFGs and OSFs jointly with its pool of foreign exchange. An alternative would be to split the foreign assets into a liquidity portfolio for balance of payment purposes and an investment portfolio for longer-term savings, with BEAC exercising oversight and countries consulted on investment strategies. This change is even more pressing given the exclusion of long-term deposits from the pool on which the share of reserves going to the operations account is calculated, effective July 1, 2007.

- $\quad$ Providing guidance on the foreign reserves target. The BEAC forecasts foreign exchange cover in light of the balance of payments position of its members. But the bank has yet to establish a framework to assess what is a desirable target for foreign exchange reserves. It should have a clear view of the level of reserves needed to support the exchange rate arrangement and define criteria for assessing the necessary and desirable level of reserves for the region, including the weight to be attached to the credibility of the exchange rate regime, short term debt considerations, potential liberalization of limits on banks' open positions, and the need to safeguard against possible adverse oil price and other terms of trade shocks.

- Improving BEAC's reserve management practices. The BEAC has traditionally kept a higher-than-required percentage of reserves in the operations account. The

\footnotetext{
${ }^{5}$ IMF (2007).
} 
lowering of the share of foreign exchange reserves to be held with the French Treasury from 65 percent in early 2007 to 50 percent in 2009 allows the BEAC to manage a larger share of reserves, directly or through external managers. While the BEAC can make deposits above that limit, it would entail a rate that is 100 basis points below the remuneration offered on the Operations Account. Increases in assets managed by the BEAC should aim at keeping operational and financial risks low.

- Providing the right incentives to save oil wealth. Growing fiscal surpluses in several countries have brought to the forefront the financial arrangements between the $\mathrm{BEAC}$ and CEMAC governments. This has prompted a review of these arrangements to make deposits at the $\mathrm{BEAC}$ more attractive. While the existing remuneration rule has been able to safeguard BEAC profitability, member countries have expressed the view that remuneration was too low. For instance, yields on 5-year government bonds in the euro area were 4 percent as of April 2007 (Figure 10) compared to FFG's rates of 3.3 percent at the BEAC. Reports of evasion of the requirement for repatriating export proceeds suggest weak incentives for members to channel all export receipts through the BEAC.

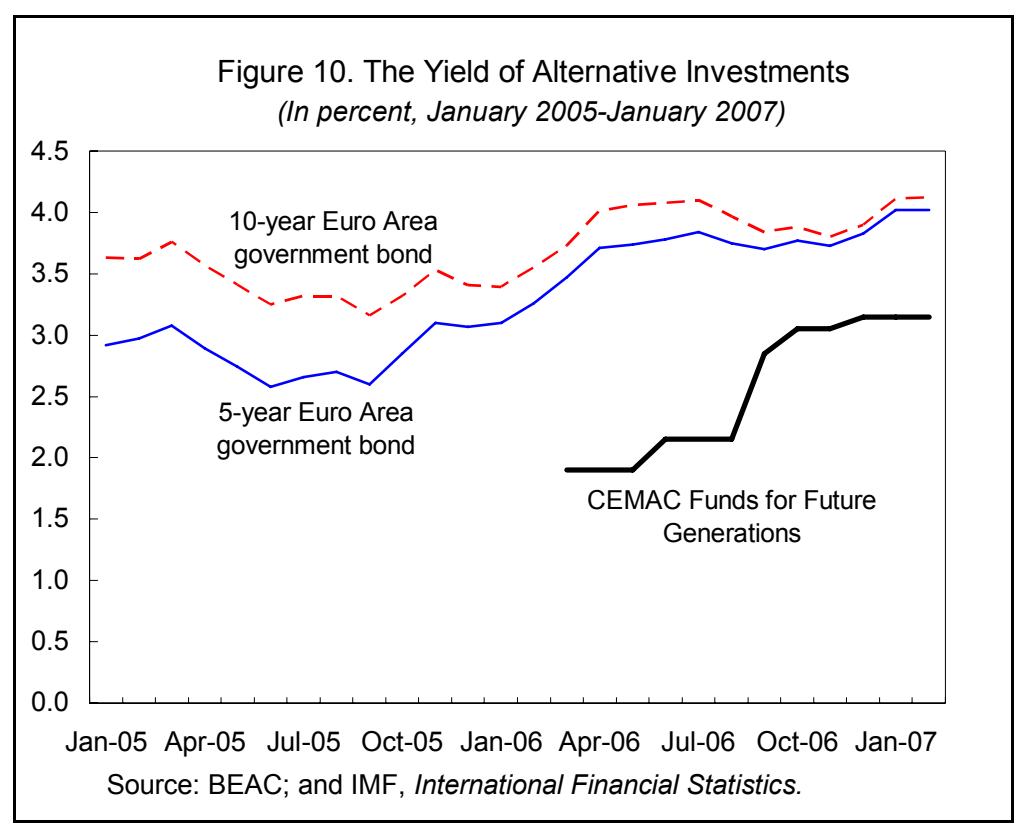

\section{Managing reserves}

19. Reserve management in line with an oil savings framework would require (i) a clear distinction between monetary reserves and other saving funds, (ii) a mechanism to keep reserve coverage adequate, and (iii) sound asset management strategies.

Monetary reserves should continue to be invested with a view to safety and liquidity. Other funds, such as FFGs, should be invested in longer-term instruments that earn a higher return, thus giving member governments incentives to save. Implementing such a framework 
requires action on three fronts: assessing reserve adequacy, keeping reserve coverage adequate, and managing foreign assets.

\section{Assessing reserve adequacy}

20. The adequacy of reserves needs to always be viewed in the broader context of macroeconomic policies. A specific level of reserves may be adequate when alternative sources of financing exist or adjustment can be quickly attained. The same level of reserves, however, may not be adequate if there are no alternative sources of financing, no exchange rate instrument, and/or a reluctance or inability to correct a current account deficit. The reserve indicators considered below are therefore useful for operational purposes but they should be considered indicative rather than definitive.

\section{Several traditional measures of foreign exchange reserves cover convey useful information on adequacy:}

- In the face of oil price volatility, and risks inherent to the supply of oil, current account-based measures - gross official reserves in months of imports - are particularly useful for CEMAC countries, as an indication of how rapidly the CEMAC would need to adjust to external shocks. It helps quantify the time in which the region could continue its level of imports if its export earnings were to drop and additional financing were unavailable. At end-2006, reserves covered 5.5 months of imports.

- As a region subject to potential capital outflows, capital account-based measures of reserve adequacy are also important. At end-2006, reserves covered over 5 times short-term debt, 2 times reserve money, and 100 percent of broad money.

22. It is not easy to define a precise threshold for these measures that would ensure the sustainability of the exchange rate regime. As the literature on vulnerability assessment has made clear, a large number of economic fundamentals, besides international reserves, can amplify the impact of adverse shocks and render a country crisis-prone in the event of a shock. These include risky short-term financing structures; stock imbalances due to maturity, currency, and interest rate mismatches; and high leverages in public and private sector balance sheets. For the CEMAC, the impact of factors such as institutional safeguards, the availability of credit lines, and the value of foreign guarantees are also important, but difficult to quantify. 
23. Reserve levels of other monetary unions and of CEMAC in the past may offer some yardsticks for adequacy. ${ }^{6}$ Reserve levels for the CEMAC today far exceed those before the 1994 devaluation and for 1994 through 2002. They are also higher than those of other monetary unions (Table 1 and Figure 11). But with structural changes affecting balance of payments flows, vulnerability to macroeconomic shocks, and the diverse vulnerabilities of different monetary unions, the experience of BEAC in previous years and that of other monetary unions provide only limited guidance about the adequate level of reserves in future.

Table 1. Comparisons of International Reserves across Regions, 1995-2006

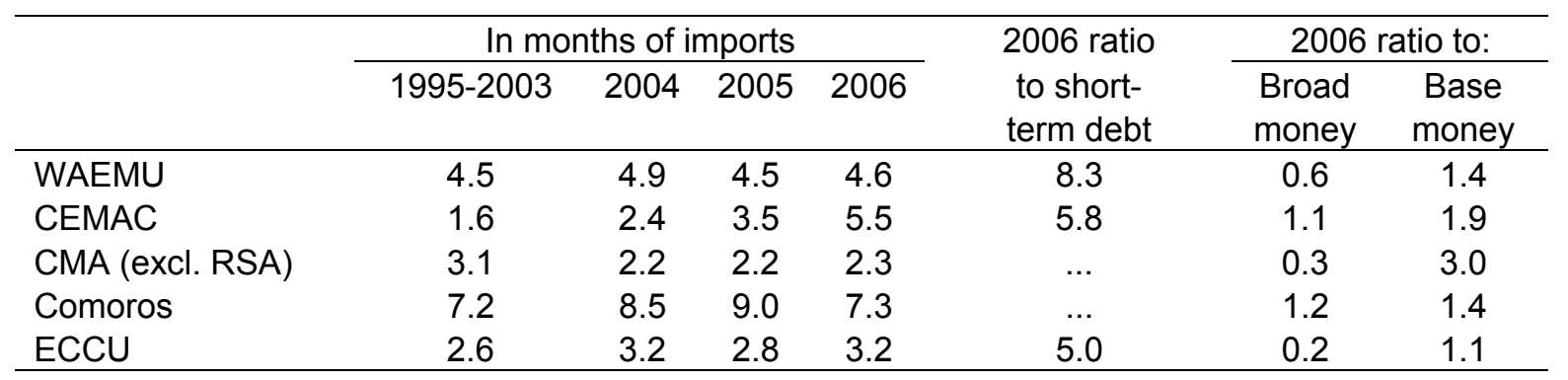

Source: IMF Staff estimates.

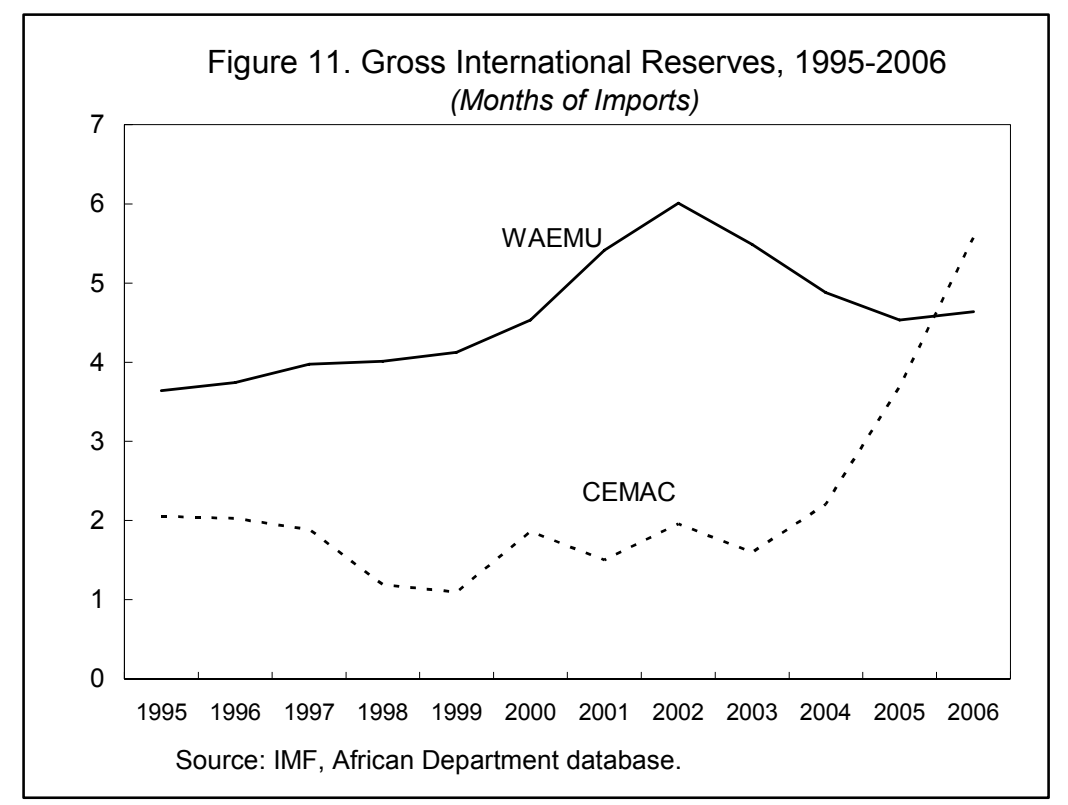

24. Notwithstanding difficulties, the BEAC, like all central banks, needs to find an operational way to express reserve targets. In the rest of this section we propose to assess the adequacy of reserves based on three criteria: thresholds given by analysis of currency and

\footnotetext{
${ }^{6}$ See IMF documents "Debt- and Reserve-Related Indicators of External Vulnerability,” March 23, 2000; "Issues in Reserves Adequacy and Management," October 15, 2001; and "Reserve Adequacy in a Currency Union: The Case of the CEMAC Region “ (IMF Country Report No. 05/390), November 2005.
} 
capital account crises, ${ }^{7}$ likelihood of macroeconomic shocks in the CEMAC, and a model for the optimal level of reserves.

\section{Thresholds}

\section{The literature on currency crises and vulnerability assessment provides useful} information on thresholds for reserve cover. The Board paper "Assessing Vulnerabilities and Crisis Risks in Emerging Market Countries" defines thresholds that splits the observations on foreign reserves (and other vulnerability indicators) for a set of 48 countries according to crisis and non-crisis sub-samples, following a decision rule that minimizes the sum of missed crises (in percent of all crisis observations) and false alarms (in percent of all non-crisis observations). The indicator of choice is the ratio of reserves to short-term-debt, or, alternatively, short-term debt and the current account, as a measure of short-term financing needs in the event of crisis. Figures $12 \mathrm{a}$ and $12 \mathrm{~b}$ suggest that for the first time in many years, the current CEMAC reserve cover indicators - with respect to short-term debt and short-term debt plus the current account balance-are above the relevant thresholds.

Figure 12a. Thresholds for International Reserves, 1995-2005 (Ratio)

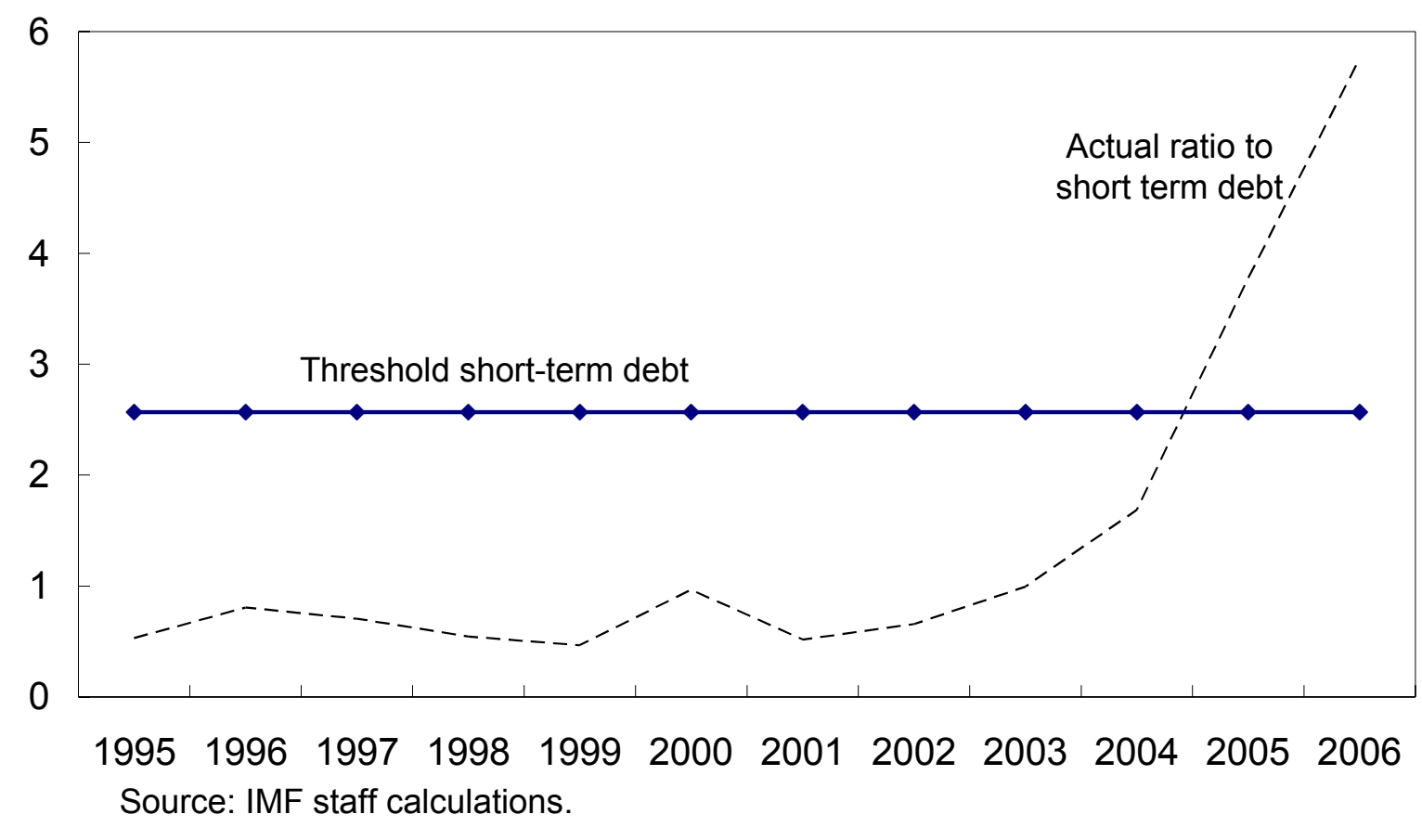

\footnotetext{
${ }^{7}$ See the IMF Paper on "Assessing Vulnerabilities and Crisis Risks in Emerging Market Countries," 2007; Ghosh et al. (2002) for a review of 8 crises; and Berg, Borenztein and Patillo (2005) for a discussion of Early Warning System models.
} 
Figure 12b. Thresholds for International Reserves 1995-2005

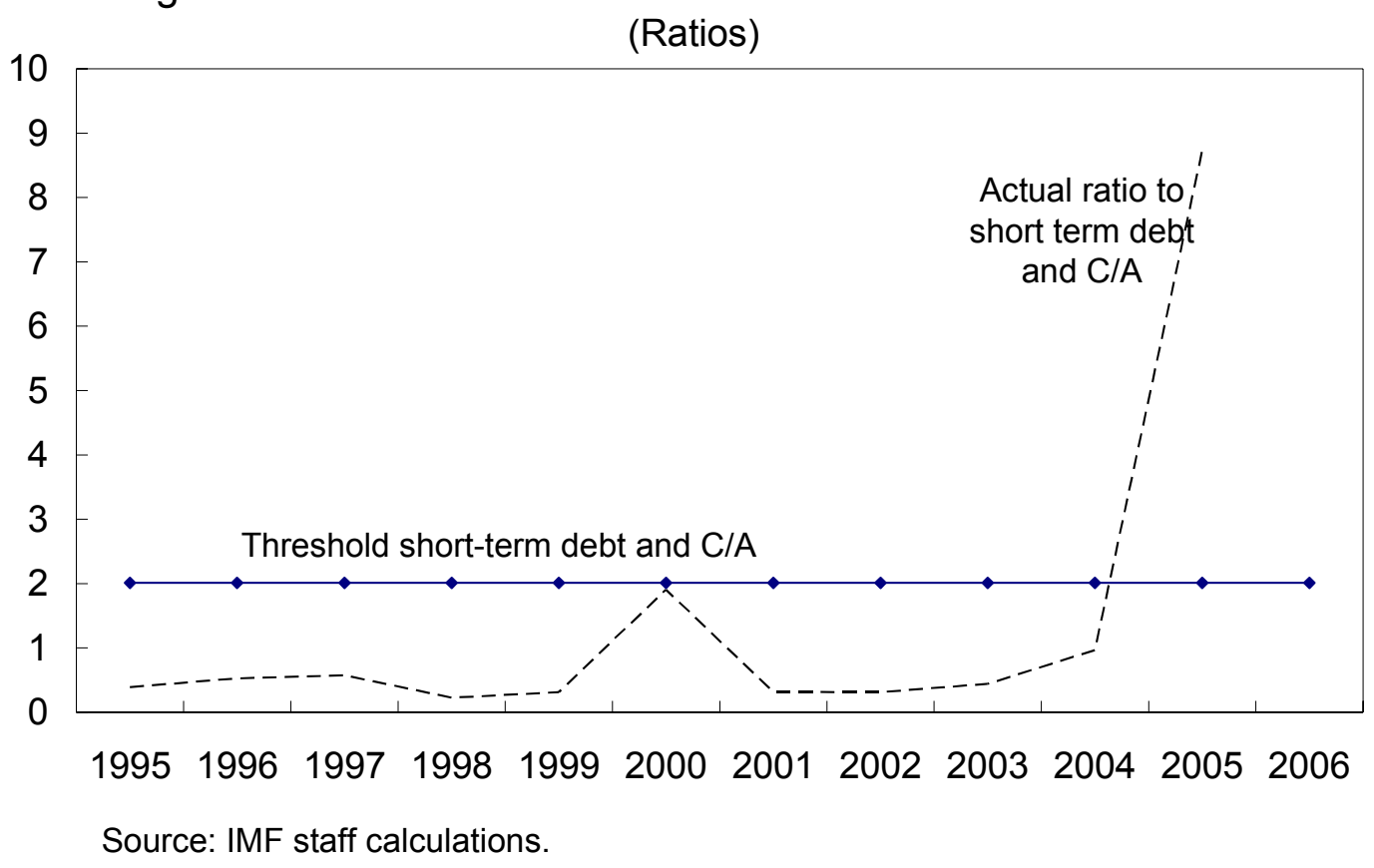

\section{Likelihood of shocks}

26. Risks from external shocks are likely to be the biggest threat to macroeconomic stability outside the authorities' control. With balance of payment instability emanating fundamentally from the current account, there is some logic in judging the adequacy of reserves against the size of current account shocks. Table 2 shows the standard deviation of the current account as a share of GDP for 1991-2006, and the reserve coverage that would be needed to accommodate a two-standard deviation shock. ${ }^{8}$ The indicators for the zone as a whole incorporate the benefits from reserve pooling. In the case of the CEMAC, to cover a two standard deviation current account shock, import coverage should amount to about 7 months of imports for the average country. For the zone as a whole, however, reflecting the benefit of pooling reserves and lower propensity to shocks in the aggregate, about 5 months coverage would suffice.

\footnotetext{
${ }^{8}$ Current-account variability largely reflects terms of trade shocks. For an earlier application, see Delechat and Martijn (2006).
} 
Table 2. CEMAC: Implied Reserve Need

\begin{tabular}{lrr}
\hline & \multicolumn{2}{c}{ Current $^{\text {Account }}{ }^{1}$} \\
\cline { 2 - 3 } & \multicolumn{2}{c}{$\begin{array}{c}\text { Implied } \\
\text { reserve } \\
\text { need }^{3}\end{array}$} \\
\hline CEMAC (Average) & 9.2 & 5.2 \\
Country average & 15.1 & 7.1 \\
Cameroon & 1.3 & 1.5 \\
Central African Rep. & 2.2 & 2.4 \\
Chad & 25.1 & 14.6 \\
Congo, Republic of & 17.6 & 8.2 \\
Equatorial Guinea & 35.4 & 9.8 \\
Gabon & 8.8 & 6.1 \\
\hline
\end{tabular}

Source: IMF, World Economic Outlook.

${ }^{1}$ As a share of GDP.

${ }^{2}$ Standard deviations of annual flows, 1991-06.

${ }^{3}$ Reserve coverage in months of imports needed to cover a two-standard-deviation shock.

Optimal level of reserves: insurance approach

27. One strand of the literature sees foreign reserves as insurance against the risk of balance of payment crises, allowing the government to smooth domestic absorption. Foreign reserves can help ensure an economy against current and capital account crises. The cost of holding reserves is that they yield a lower return than the interest rate that the government must pay on its long-term external liabilities. The optimal level of reserves depends on a country's vulnerability to a crisis, the magnitude of a likely crisis, and the opportunity cost of holding reserves (Box 2).

28. Reserves are accumulated to lower the probability of a crisis and its welfare cost. In the case of the CEMAC, it would make sense to think of potential crises induced by negative terms of trade shocks driven by a decline in oil prices. For illustrative purposes, we calibrate the Jeanne-Ranciere model for the optimal level of reserves using data from 1991 through 2006 for the CEMAC countries (Box 2, Table 3). The assumptions used are as follows:

- $\quad$ The size of shock is estimated to replicate the largest yearly increase in the current account for the CEMAC during the period.

- The cumulative output loss is assumed to range between 6.5 percent and 10 percent in the year of the shock and the year following.

- $\quad$ The probability of a shock is set to fall between 10 and 15 percent. 
Our benchmark calibrations suggest the actual level of reserves, 14.3 percent of GDP at end2006 , is within the range of what would be considered optimal according to the parameters in Table 3.

\section{Box 2. Insurance and Optimal Level of Reserves}

A number of recent studies look into the precautionary role of reserves and derive a closed form solution for the optimal level based on dynamic optimization (Jeanne and Ranciere, 2007; Becker et al, 2007; Hauner, 2005). In these models, the optimal level of reserves depends on the vulnerability to a crisis, its magnitude, and the opportunity cost of holding reserves. The optimal level of reserves can be written as a fraction of the level of output,

$$
R_{t}=\rho Y_{t+1}^{b},
$$

where the optimal reserves-to-output ratio $\rho$ is given by

$$
\rho=\lambda+\gamma-\frac{p^{\frac{1}{\sigma}}-1}{1+\left(p^{\frac{1}{\sigma}}-1\right)(1-\delta-\pi)}\left[1-\frac{r-g}{1+g} \lambda-(\delta+\pi)(\lambda+\gamma)\right]
$$

Where $\lambda$ is the size of a shock, $\gamma$ is the fall in output as a result of the shock, $p$ is the relative price of consumption between shock and no-shock states, $\delta$ is the term premium, $\pi$ is the probability of a shock, $\mathrm{r}$ is the risk free interest rate, $\mathrm{g}$ is the potential output growth rate, and $\sigma$ is a coefficient of risk aversion.

Table 3. Optimal Level of Reserves - Calibration of Parameters

\begin{tabular}{llll}
\hline$\lambda$ & 0.107 & 0.107 & Size of shock: largest yearly drop in the current account deficit \\
$\mathrm{Y}$ & 0.065 & 0.100 & Output loss: fall in growth rate of GDP in t and $\mathrm{t}+1$ \\
$\sigma$ & 2.000 & 2.000 & Risk aversion \\
$\pi$ & 0.100 & 0.150 & Probability of shock - unconditional \\
$\delta$ & 0.015 & 0.015 & Term premium \\
$\mathrm{g}$ & 0.066 & 0.066 & Potential output growth \\
$\mathrm{r}$ & 0.050 & 0.050 & Risk free rate; return on reserves
\end{tabular}

OPTIMAL RESERVES-TO-OUTPUT RATIO

\begin{tabular}{cccc}
$\rho$ & 0.172 & 0.207 & Assumes output loss, but relative prices constant in times with or without shocks \\
$\rho$ & 0.097 & 0.153 & Olivier-Ranciere (assumes output loss, and relative prices increase during shocks) \\
\hline Source: IMF staff estimates.
\end{tabular}

\section{Keeping reserve coverage adequate}

29. While current reserves seem adequate now, oil-based savings should be planned in terms of keeping reserves adequate into the future. Given that oil represents 80 percent of the region's exports, oil-related inflows will have to form the bulk of reserves. However, considering the country specific and long-term purpose of revenue deposited in saving funds like FFGs, the foreign currency counterparts to these funds should not count as part of the pooled monetary reserves. There is a need within the BEAC to separate FFG accounts from monetary reserves because they have different purposes and should these be invested 
different risk and return profiles with implications for the amount of fiscal savings that may be channeled to these funds.

30. What is the size of country-owned savings that can be accommodated consistent with maintaining monetary reserves at an adequate level? The answer to this question depends on a number of factors including the baseline profile of reserves accumulation, the projected size of oil reserves, and the projected stream of oil inflows. Calibrating the size of country-owned savings compatible with adequate level of monetary reserves will require continuous monitoring by the BEAC with a view to incorporate in its monetary programming the medium-term balance of payment forecast of member countries, including projected oil inflows.

\section{For illustrative purposes, Figure 13 projects the baseline reserves and medium-}

term coverage. The scenario is based on WEO balance of payments projections for member countries and alternative assumptions for the share of oil revenues saved under FFGs. The projections suggest that saving about a quarter of overall projected oil inflows would be consistent with maintaining through 2012 the reserve coverage prevailing at the end of 2006 . This compares with under 3 percent of oil revenues saved into FFGs at the end of 2006. Next, we simulate the long-term impact of alternative savings ratios on reserve coverage as deviations from baseline (i.e., WEO projections). Figure 14 suggests FFG savings would be equivalent to 0 to 3 months of imports, under different assumptions. Savings fade overtime reflecting the temporary nature of oil revenues. The actual share of savings and monetary reserves will vary for each country and will depend on such factors as how the overall balance of payment actually evolves for the CEMAC. These calculations show, however, that there seems to be scope for increasing the level of country-owned savings for the region as a whole consistent with preserving reserve coverage over the medium-term.

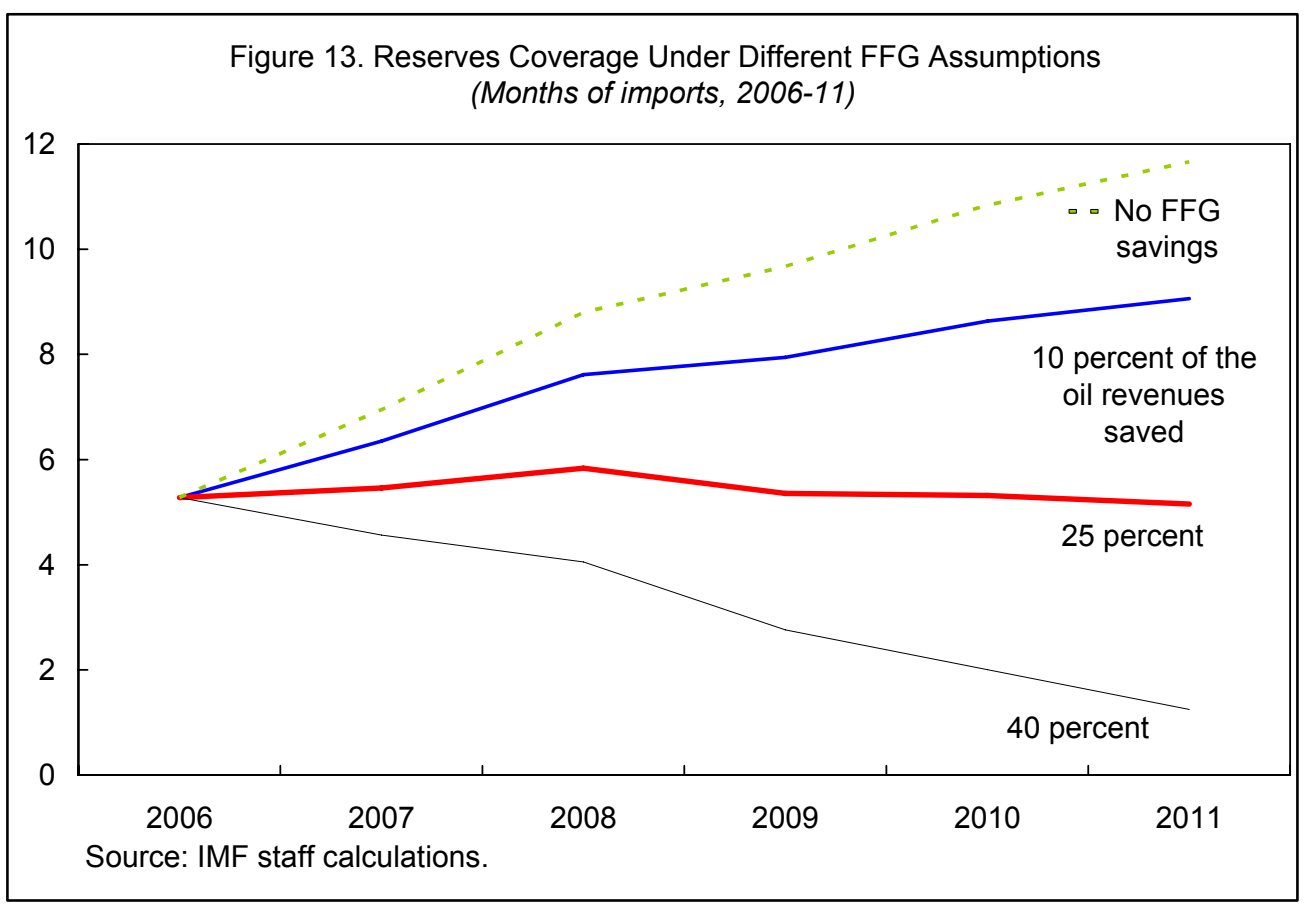




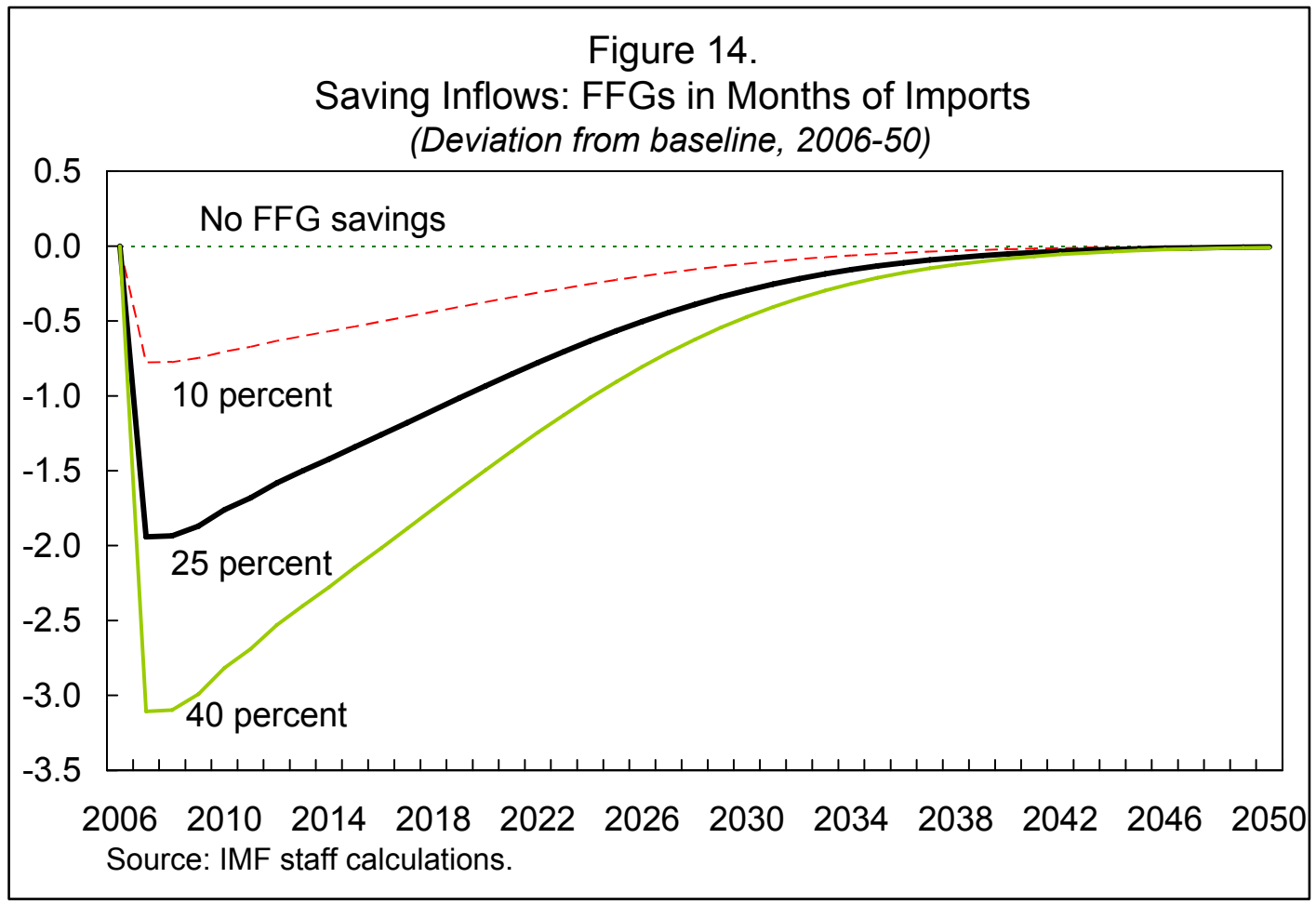

32. The previous analysis abstracts from conditions under which country owned-funds could, if necessary, be used to preserve CEMAC reserve accumulation. With oil related inflows set to increase for the CEMAC, the BEAC and member countries could agree on conditions under which, if there are shortfalls in reserve accumulation, the bank would have the opportunity to tap into longer term savings to make up for the shortfall. The proportion of savings that would remain under the control of the monetary authorities would thus depend on specific conditions for withdrawal for short-term use from country own funds that had been put under BEAC control. The setting of such conditions would be an important consideration affecting the level of country savings other than contributions to the common reserve pool. ${ }^{9}$

\section{Managing foreign assets}

33. The accumulation of foreign assets beyond the level considered sufficient for balance of payments needs should allow CEMAC countries to invest oil income in longer-term assets. Designing and managing an investment portfolio for longer-term savings raises a number of issues for the BEAC:

\footnotetext{
${ }^{9}$ Current arrangements on the operations account with France allow the BEAC to tap into longer term savings of member countries and countries' foreign assets held abroad to make up for reserves shortfall.
} 
- $\quad$ The need to establish a strategic allocation of assets (SAA) for which BEAC assumes management responsibility in close collaboration with CEMAC countries, in line with governments' choices and consistent with the founding principles of the Franc Zone (Box 3).

- $\quad$ The need to consider the feasibility of adopting a structure for the investment portfolio that would be akin to an Oil Fund, managed separately from the liquidity portfolio.

- $\quad$ The need to consult with governments on a legal structure conducive to a clear separation between the liquidity and investment portfolios in terms of governance, operational management, and risks.

- $\quad$ The need to reach an agreement on the implementation of the solidarity principle in the event BEAC international reserves fall below the desired level.

\section{Box 3. The Concept of Strategic Asset Allocation}

The strategic allocation of assets (SAA) aims to achieve investment objectives for a given investment horizon and risk taking.

The strategy has the following components: (i) determining the size of the portfolio(s) and setting targets for returns, if the level of reserves is sufficiently high to create national savings; (ii) defining the investment horizon(s); a few months for the liquidity portfolio, several years for the investment portfolio; (iii) defining a budget for risk and what constitutes an undesirable return.

Implementing the strategy requires defining a strategic benchmark, with an optimal risk/return ratio. This benchmark is different for each institution. It is based on a specific reserve currency composition and a particular exposure to different categories of financial assets. Some institutions distinguish the strategic allocation, namely the definition of the optimum long-term portfolio, from the tactical allocation that exploits trade-offs between different assets in order to optimize the risk/return ratio of the chosen strategy.

\section{Conclusions and Issues Going Forward}

34. This paper argues that management of the oil booms for the CEMAC countries would benefit from improvements in the existing regional reserve management

framework. The CEMAC's ambitious institutional reform agenda should allow the issues discussed in this paper to be addressed. Key areas to be addressed are:

- Determining the appropriate level of government savings in light of the need to coordinate monetary and fiscal policy;

- $\quad$ Distinguishing between monetary reserves and savings;

- $\quad$ Providing guidance on the adequacy of the foreign reserves target; 
- Improving BEAC reserve management practices; and,

- Providing the right incentives to save oil wealth.

35. The current level of foreign assets in the CEMAC, which seems sufficient for balance of payment needs, brings to the forefront issues of how to preserve reserve adequacy and how to save oil income.

- $\quad$ Oil-based savings should be compatible with keeping reserves adequate; there is some scope for increasing country savings while preserving reserve coverage over the medium-term.

- $\quad$ An appropriate asset management strategy is both required and desirable so that country-owned funds can potentially receive large amounts of resources. In the absence of such a strategy, the incentives underlying the saving-spending decision at the country level would be distorted. There must also be an effective strategy to provide incentives for repatriating to the BEAC all foreign exchange revenues. Such a strategy could allow BEAC to continue coordinating these funds but would seek to adopt clear, comprehensive, and transparent investment and risk management. 


\section{References}

Becker, Torbjorn, and others, 2007, Country Insurance-The Role of Domestic Policies, IMF Occasional Paper No. 254 (Washington: International Monetary Fund).

Berg, Andrew, and others, 2005, Assessing Early Warning Systems, How have they worked in Practice, IMF Staff papers 9/1/05, (Washington: International Monetary Fund).

— 2007, The Macroeconomics of Scaling Up Aid, IMF Occasional Paper 253, (Washington: International Monetary Fund)

Bower, Uwe, and others, 2007, Commodity Price Fluctuations and their Impact on Monetary and Fiscal Policies in Western and Central Africa, ECB Occasional Paper No. 60, April 2007, (European Central Bank).

Clément, Jean A.P., and others, 1996, Aftermath of the CFA Franc Devaluation, IMF Occasional Paper No. 138 (Washington: International Monetary Fund).

Davis, Jeffrey, and others, 2001, "Stabilization and Savings Funds for Nonrenewable Resources: Experience and Policy Implications," IMF Occasional Paper No. 205 (Washington: International Monetary Fund).

Deléchat, Corinne, 2005 "Reserve Adequacy in a Currency Union-The Case of the CEMAC Region,” in CEMAC, Selected Issues, IMF Country Report No. (05/198) (Washington: International Monetary Fund).

— Convertibility Guarantee," IMF Working Paper (Washington: International Monetary Fund, forthcoming).

Espinosa, Marco, and Mercedes Vera-Martin, 2004, “On Chile’s Holdings of Foreign Reserves," in Chile-Selected issues, IMF Country Report No. 04/261 (Washington: International Monetary Fund).

Gereirat, C., 2005, "Managing Oil Revenues in Gabon-Is there a Role for the Fund for Future Generations?" in Gabon, Selected Issues and Statistical Appendix, IMF Country Report No. 05/147 (Washington: International Monetary Fund).

Ghosh et. al., 2002, IMF Supported Programs in Capital Account Crises, IMF Occasional Paper 210 (Washington: International Monetary Fund). 
Hadjimichael, Michael T., and Michel Galy, 1997, "The CFA Franc Zone and the EMU," IMF Working Paper 97/156 (Washington: International Monetary Fund).

Hauner, David, 2005, “A Fiscal Price Tag for International Reserves,” IMF Working Paper 05/81 (Washington: International Monetary Fund).

International Monetary Fund, 2007, The Role of Fiscal Institutions in Managing the Oil Revenue Boom, IMF Board Paper SM/07/88.

International Monetary Fund, 2007, Assessing Vulnerabilities and Crisis Risks in Emerging Market Countries-A New Approach, IMF Background Paper.

Jeanne, Olivier and Romain Ranciere, 2006, The Optimal level of International Reserves for Emerging Market Countries: Formulas and Applications, WP/06/229 (Washington: International Monetary Fund).

Laurens, B., and others, 2006, CEMAC-Financial Sector Stability Assessment, IMF Country Report 06/321 (Washington: International Monetary Fund). 